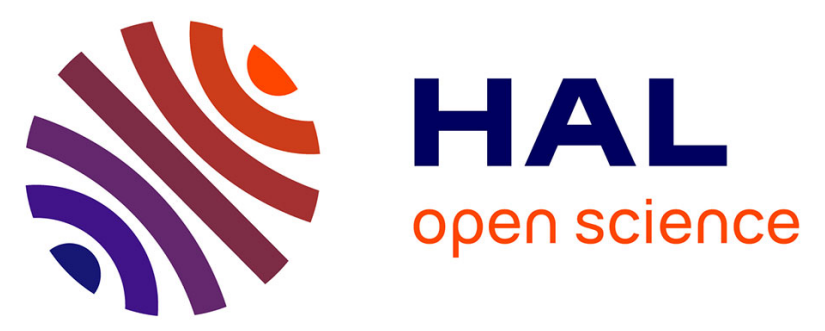

\title{
Vapor pressure deficit and sunlight explain seasonality of leaf phenology and photosynthesis across amazonian evergreen broadleaved forest
}

Xiuzhi Chen, Philippe Ciais, Fabienne Maignan, Yuan Zhang, Ana Bastos, Liyang Liu, Cédric Bacour, Lei Fan, Pierre Gentine, Daniel Goll, et al.

\section{To cite this version:}

Xiuzhi Chen, Philippe Ciais, Fabienne Maignan, Yuan Zhang, Ana Bastos, et al.. Vapor pressure deficit and sunlight explain seasonality of leaf phenology and photosynthesis across amazonian evergreen broadleaved forest. Global Biogeochemical Cycles, 2021, 35 (6), pp.1-15. 10.1029/2020GB006893 . hal-03277337

\section{HAL Id: hal-03277337 \\ https://hal.science/hal-03277337}

Submitted on 3 Jul 2021

HAL is a multi-disciplinary open access archive for the deposit and dissemination of scientific research documents, whether they are published or not. The documents may come from teaching and research institutions in France or abroad, or from public or private research centers.
L'archive ouverte pluridisciplinaire HAL, est destinée au dépôt et à la diffusion de documents scientifiques de niveau recherche, publiés ou non, émanant des établissements d'enseignement et de recherche français ou étrangers, des laboratoires publics ou privés. 
Global

\section{Biogeochemical Cycles}

\section{RESEARCH ARTICLE \\ 10.1029/2020GB006893 \\ Key Points: \\ - The new canopy phenology module captures the large-scale spatial and seasonal patterns of Amazonian forest photosynthesis \\ - Vapor pressure deficits and sunlight explain seasonality of Amazonian forest phenology and photosynthesis \\ - This study for the first time integrates site-level process knowledge to match diagnostic evidence at large scale across Amazonian forests}

\section{Supporting Information:}

Supporting Information may be found in the online version of this article.

Correspondence to:

X. Chen,

chenxzh73@mail.sysu.edu.cn

Citation:

Chen, X., Ciais, P., Maignan, F., Zhang, Y., Bastos, A., Liu, L., et al. (2021). Vapor pressure deficit and sunlight explain seasonality of leaf phenology and photosynthesis across Amazonian evergreen broadleaved forest. Global Biogeochemical Cycles, 35, e2020GB006893. https://doi. org/10.1029/2020GB006893

Received 25 NOV 2020 Accepted 3 MAY 2021 (c) 2021. American Geophysical Union. All Rights Reserved.

\section{Vapor Pressure Deficit and Sunlight Explain Seasonality of Leaf Phenology and Photosynthesis Across Amazonian Evergreen Broadleaved Forest}

\begin{abstract}
Xiuzhi Chen $^{1,2,3}$ (D), Philippe Ciais ${ }^{2}$, Fabienne Maignan $^{2}$ (D), Yuan Zhang ${ }^{2,4}$ (D), Ana Bastos $^{2,5}$ (D), Liyang Liu' ${ }^{2}$, Cédric Bacour ${ }^{6}$ (D), Lei Fan ${ }^{7,8}$, Pierre Gentine ${ }^{9}$ (iD, Daniel Goll ${ }^{2,10}$ (D), Julia Green ${ }^{2,9}$, Hyungjun Kim ${ }^{11}$ (D), Laurent Li $^{4}$, Yi Liu ${ }^{7}$, Shushi Peng ${ }^{12}$ (D), Hao Tang ${ }^{13}$, Nicolas Viovy ${ }^{1}$, Jean-Pierre Wigneron ${ }^{7}$ (D), Jin $\mathrm{Wu}^{14}$, Wenping Yuan ${ }^{1,3}$, and Haicheng Zhang ${ }^{2}$

${ }^{1}$ Guangdong Province Key Laboratory for Climate Change and Natural Disaster Studies, School of Atmospheric Sciences, Sun Yat-sen University, Zhuhai, China, ${ }^{2}$ Laboratoire des Sciences du Climat et de l'Environnement, IPSL, CEA-CNRS-UVSQ, Université Paris-Saclay, Gif sur Yvette, France, ${ }^{3}$ Southern Marine Science and Engineering Guangdong Laboratory (Zhuhai), Zhuhai, China, ${ }^{4}$ Laboratoire de Météorologie Dynamique, CNRS, Sorbonne Université, École Normale Supérieure, École Polytechnique, Paris, France, ${ }^{5}$ Department of Geography, LudwigMaximilians University, Munich, Germany, ${ }^{6}$ NOVELTIS, Labège, France, ${ }^{7}$ Collaborative Innovation Center on Forecast and Evaluation of Meteorological Disaster, School of Geographical Sciences, Nanjing University of Information Science and Technology, Nanjing, China, ${ }^{8}$ ISPA, UMR 1391, INRAE Nouvelle-Aquitaine, Bordeaux Villenave d'Ornon, France, ${ }^{9}$ Department of Earth \& Environmental Engineering, Columbia University, New York, NY, USA, ${ }^{10}$ Institute of Geography, University of Augsburg, Augsburg, Germany, ${ }^{11}$ Institute of Industrial Science, University of Tokyo, Tokyo, Japan, ${ }^{12}$ Sino-French Institute for Earth System Science, College of Urban and Environmental Sciences, Peking University, Beijing, China, ${ }^{13}$ Department of Geographical Sciences, University of Maryland, College Park, MD, USA, ${ }^{14}$ School of Biological Sciences, The University of Hong Kong, Pokfulam, Hong Kong
\end{abstract}

Abstract Amazonian evergreen forests show distinct canopy phenology and photosynthetic seasonality but the climatic triggers are not well understood. This imposes a challenge for modeling leaf phenology and photosynthesis seasonality in land surface models (LSMs) across Amazonian evergreen forest biome. On continental scale, we tested two climatic triggers suggested by site observations, vapor pressure deficit (VPD), and short-wave incoming radiation (SW) for defining leaf shedding and incorporated VPD- and SW-triggered new canopy phenology modules in the ORCHIDEE LSM (hereafter VPD-AP and SW-AP versions). Our results show that both VPD and SW are plausible precursors of large scale litterfall seasonality across the basin by comparing against in situ data from 14 sites. Specially, both VPD-AP and SW-AP correctly capture the increases in litterfall during the early dry season, followed by a flush of new leaves with increasing photosynthetic rates during the later dry season. The VPD-AP version performs better than the SW-AP version in capturing a dry-season increase of photosynthesis across the wet Amazonia areas where mean annual precipitation exceeds 2,000 $\mathrm{mm} \mathrm{yr}^{-1}$, consistent with previous satellite data analysis. Both VPD-AP and SW-AP model versions perform well in northern, central and southern Amazon regions where the SW seasonality is unimodal, but miss the seasonality of satellite GPP proxies in the eastern region off the coast of Guyana shield where SW seasonality is bimodal. Our findings imply that atmospheric dryness and sunlight availability likely explain the seasonality of leaf shedding and leaf flush processes, respectively, and consequently control canopy photosynthesis in Amazonian evergreen forests.

\section{Introduction}

Wet tropical forests regulate the global exchange of carbon dioxide, energy, and water fluxes between the land surface and the atmosphere. They account for $34 \%$ of global annual terrestrial photosynthesis (gross primary production, GPP) (Beer et al., 2010) and provide more than $75 \%$ of rainwater recycling in tropical rainforests through plant evapotranspiration (Spracklen et al., 2012; van den Ent et al., 2014). Despite a perennial canopy, wet tropical forests shed and rejuvenate their leaves, leading to litterfall and photosynthesis peaks at different seasons across sites in humid tropical forests (Saleska, Miller, et al., 2003; Sayer et al., 2011; Leff et al., 2012). Understanding the seasonal variations of leaf phenology (leaf flush and litterfall) and their 
impact on photosynthesis also offers insights into how they may respond to climate change, e.g., longer dry seasons in southern Amazon (Boisier et al., 2015).

Eddy-covariance (EC) measurements in Amazonian evergreen forests, the focus of our study, are sparse, but most sites record an increase of photosynthetic rates in the dry season (de Weirdt et al., 2012; Manoli et al., 2018; Restrepo-Coupe et al., 2013, 2017; Saleska, Miller, et al., 2003; Xu, Saatchi, et al., 2015). A key plant trait linking seasonal variations of leaf properties with photosynthesis seasonality was shown to be leaf age (Albert et al., 2018; Wu, Guan, et al., 2017; Xu, Medvigy, et al., 2017). Young leaves are observed to take advantage of the increase in surface radiation in the dry season and increase canopy photosynthesis (Anber et al., 2015; Wu, Serbin, et al., 2017). The fall of old leaves as litter followed by the flush of new leaves in the late wet season triggers an increase of canopy photosynthesis through the subsequent dry season because young leaves have a higher light use efficiency (Wu, Albert, et al., 2016). This process is relatively well documented from EC data (Wu, Albert, et al., 2016) and biometric measurements of canopy foliage productivity (Doughty, Metcalfe, et al., 2015) in both humid low- and dry-land Amazonian forests.

In contrast, diagnosing whether photosynthesis increases or decreases during the dry season period across different Amazon regions requires the use of satellite products. Satellite optical remote sensing detect canopy green-up during the dry season in parts of Amazonian evergreen forests (Huete et al., 2006; Saleska, Wu, et al., 2016; Xiao, Zhang, et al., 2005). However, such a dry-season green-up pattern has been questioned (Morton et al., 2014; Samanta et al., 2010, 2011a, 2011b) due to the near-infrared reflectance changes induced by cloud/aerosols contaminations and surface anisotropy, as observed using varying sensor and illumination geometries. Recent analyses of optical data from multiple sensors show that Solar-Induced Fluorescence (SIF) can be used as an arguably better proxy of GPP than optical data (Doughty, Köhler, et al., 2019; Lee et al., 2013; Xu, Saatchi, et al., 2015), and that the Enhanced Vegetation Index (EVI) (Huete et al., 2006; Lopes et al., 2016; Wu, Kobayashi, et al., 2018) (Supplementary Texts: A) can be considered as a proxy for leaf area change and new leaf flush. Combining above datasets, studies confirmed some regions of Amazonia become greener in the dry season period (Badgley et al., 2017; Guan, Pan, et al., 2015), however, with nonuniform seasonal patterns (Bi et al., 2015; Parazoo et al., 2013). Moreover, independent spaceborne Lidar observations of canopy structure also suggest a dry-season increase of canopy volume across the Amazon (Tang \& Dubayah, 2017).

The key point is that forests in different sub-regions of Amazonia experience different seasonal constraints of water and light availability during recurrent dry and wet seasons (Brando et al., 2010; Chen et al., 2020; Davidson et al., 2012; Xiao, Zhang, et al., 2005) and thus show distinct canopy phenology and GPP seasonality (Chen et al., 2020; Xu, Saatchi, et al., 2015). The underling mechanisms linking seasonal water and light availability with litterfall and photosynthetic seasonality remain elusive and likely differ between regions (Leff et al., 2012; Saleska, Miller, et al., 2003; Sayer et al., 2011). Many data suggested that most forests in the Amazon have deeper rooting system to access sufficient ground water supply during the dry seasons so that soil water is not the limitation causing litterfall and dry-season leaf rejuvenation is due to the increases in sunlight availability (Huete et al., 2006; Lee et al., 2013; Tang \& Dubayah, 2017; Wright \& Van Schaik, 1994). But Chen et al. (2020) proposed vapor pressure deficit (VPD) as a trigger for leaf phenology and photosynthetic seasonality and tested the impact of a VPD driven litterfall and subsequent canopy turnover in the ORCHIDEE model at four Amazon flux tower sites. ORCHIDDE showed good performances for modeling GPP and LAI seasonality at three sites in the central Amazon, but missed the seasonality of the fourth site near the sea in French Guiana.

The scientific question addressed in this study is whether the wet- and dry- season variability in leaf shedding observed at site and regional levels is more controlled/limited by atmospheric water VPD or by sunlight availability, given that soil water is likely not the limitation for Amazon. Therefore, we tested VPD as suggested by Chen et al. (2020) from tower-based observations and SW radiation as suggested by Zhang, Yuan, et al. (2014) from evidence at several litterfall sites, as potential climatic triggers for leaf shedding. We designed and implemented VPD- and SW-triggered leaf shedding modules in gridded runs with the ORCHIDEE LSM (hereafter VPD-AP and SW-AP, respectively) simulating dynamic leaf area, canopy age and GPP over the whole Amazon evergreen forests during the 1980-2015 period. The results are evaluated against multiple satellite datasets of phenology and photosynthetic proxies. Following Guan, Pan, et al. (2015) that identified distinct dry-minus-wet-season differences in canopy phenology between northern wetter part of 
Amazonia where MAP $>2,000 \mathrm{~mm} \mathrm{yr}^{-1}$ and other regions where MAP $<2,000 \mathrm{~mm} \mathrm{yr}^{-1}$ based on GOME-2 SIF and MODIS EVI data (Supplementary Texts: A), we also checked whether VPD-AP and SW-AP simulations reproduce the same observed patterns, that is, that forests greening-up during the dry season are

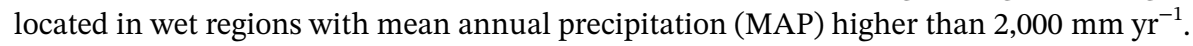

\section{Methodology, Model, and Data Sets}

\subsection{Overview of the Study Strategy}

In this study, we run both the ORCHIDEE-TRUNK (https://forge.ipsl.jussieu.fr/orchidee/wiki/SourceCode\#trunk) and ORCHIDEE-AP model versions (Chen et al., 2020) over Amazonia. The two versions differ only by the representation of canopy phenology for evergreen broadleaved forests. The models are described in Section 2.2. Given the lack of a consensus from theory or empirical knowledge about which climate variable triggers litter fall (Bi et al., 2015; Lopes et al., 2016; Huete et al., 2006; Tang \& Dubayah, 2017; Saleska, Miller, et al., 2003; Wu, Albert, et al., 2016; Xu, Saatchi, et al., 2015), we tested both the seasonal increase of VPD and of SW (see equations in Section 2.2). In the previous site-simulation paper (Chen et al., 2020), ORCHIDEE-AP only considered VPD but the present study also updated a modified formulation using SW instead of VPD, as Zhang, Yuan, et al. (2014) found that SW is a good precursor of leaf shedding. To evaluate the dominant cause of VPD or SW in driving the increase of GPP across the entire region, this study verified

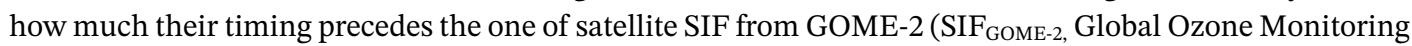
Experiment-2) (Joiner et al., 2013; 2016; Supplementary Texts: A) using a spectral phase analysis method (Bradley et al., 2011). Further, to access uncertainty related to climate forcing (including VPD and SW) used to drive land surface models (LSMs), in particular over Amazonia, we performed simulations using two different reanalyzes, with either the Climatic Research Unit - National Centers for Environmental Prediction (CRUNCEP) (Viovy et al., 2018, https://rda.ucar.edu/datasets/ds314.3/) 6-hourly or Global Soil Wetness Project Phase 3 (GSWP3) (Kim, 2017, http://hydro.iis.u-tokyo.ac.jp/GSWP3/) 3-hourly meteorological forcing data. The model parameterization is summarized in Section 2.2, the simulation setup in Section 2.3 and datasets used for evaluation in Section 2.4. Results and discussion are provided thereafter.

\subsection{Representation of Tropical Evergreen Canopy Phenology in ORCHIDEE-AP}

A detailed description of VPD-AP is given in Chen et al. (2020). The main modification of the phenology and photosynthesis modules compared to ORCHIDEE-TRUNK is that the production of new leaves and the abscission of old leaves is linked to environmental variables (Bi et al., 2015; Brando et al., 2010; Huete et al., 2006; Lee et al., 2013; Guan, Pan, et al., 2015; Wu, Albert, et al., 2016; Xu, Saatchi, et al., 2015). Four leaf age classes describe the canopy demography. Leaf class 1 represents the youngest age cohort and class 4 represents the oldest one. The four leaf age classes are characterized by their fraction of leaf biomass and mean age. At each time step, a fraction of the biomass of the younger leaf class turns over to the next age cohort until the older cohort reaches a predefined leaf life span. Then, leaves from the oldest cohort fall on the ground (Krinner et al., 2005, Appendix A, Section A4.4). The carbon allocation toward new leaves (age class 1) was parameterized as a function of SW and LAI of the oldest leaves (age class 4). The fraction of net primary productivity (NPP) allocated to new leaves is given by:

$$
f_{\text {leaf }}^{\text {new }}=\min \left[0.99,\left(S W_{\text {week }} \times e^{-0.5 L A I_{4}} / C_{1}\right)^{C_{2}} \times f_{\text {leaf }}\right]
$$

where $f_{\text {leaf }}^{\text {new }}$ and $f_{\text {leaf }}$ are the modified and standard allocation fractions of NPP to leaves (carbohydrates entering age class 1); $S W_{\text {week }}$ is the weekly mean shortwave downwelling solar radiation, $L A I_{4}$ is the LAI of the oldest leaf age class 4, $\mathrm{C} 1$ and $\mathrm{C} 2$ are empirical coefficients set to $35.0 \mathrm{~W} . \mathrm{m}^{-2}$ and 6.0 (Chen et al., 2019, in revision), calibrated from observed LAI cohorts (Wu, Albert, et al., 2016). The maximum carboxylation rate of leaves at $25^{\circ} \mathrm{C}\left(\mathrm{V}_{\mathrm{cmax}}\right)$ is a function of leaf age and was calibrated using field data from 20 tropical evergreen forests (Xu, Medvigy, et al., 2017).

The leaf shedding process from the oldest leaf age class (4) is triggered by changes in the weekly mean $V P D_{\text {week }}$ as follows: 


$$
\Delta B_{i}=B_{i} \times \min \left\{0.99,\left(V P D_{\text {week }} / C_{3}\right)^{C_{4}} \times \min \left[0.99, \frac{\Delta t}{a_{\text {crit }}}\left(\frac{a_{i}}{a_{\text {crit }}}\right)^{4}\right]\right\}
$$

where $\Delta B_{i}$ is the loss of biomass $B_{i}$ of the oldest leaves (age class $i=4$ ) at each time step $\Delta \mathrm{t} a_{i}$, is the leaf age (days) and $a_{\text {crit }}$ is a critical leaf age (days), that is the maximum longevity of a leaf (Krinner et al., 2005). The unit of $V P D_{\text {week }}$ is $\mathrm{kPa}, \mathrm{C} 3$, and $\mathrm{C} 4$ are empirical factors set to 3.0 and $2.5 \mathrm{kPa}$, respectively, calibrated from observed litter fall data from four flux sites in Amazonia (Chen et al., 2020). In Equation 2, when $V P D_{\text {week }}$ reaches the threshold $\mathrm{C} 3$, there is an acceleration of the litter fall rate, while a reduction of litter fall rate happens when $V P D_{\text {week }}$ is smaller than C3.

As an alternative to the VPD-triggered litter fall model, we also tested in this study a SW-AP version based on SW observations inspired from the studies of Taiz and Zeiger (2002) and Zhang, Yuan, et al. (2014). In SW-AP, the leaf shedding process from the oldest leaf age class 4 is set to depend on weekly SW ( $S W_{\text {week }}$ ) as follows:

$$
\Delta B_{m}=B_{m} \times \min \left\{0.99,\left[\exp \left(\frac{S W_{\text {week }}}{C_{3}}\right)-1.0\right]^{C_{6}} \times \min \left[0.99, \frac{\Delta t}{a g e_{\text {crit }}}\left(\frac{a g e_{m}}{a g e_{\text {crit }}}\right)^{4}\right]\right\}
$$

where $\mathrm{C} 5$ and $\mathrm{C} 6$ are empirical factors set to $180.0 \mathrm{~W} \mathrm{~m}^{-2}$ and 6.0 . These empirical values were also calibrated using observed litter fall data from the four tower sites in Chen et al. (2020).

\subsection{Simulation Setup}

Three versions of the ORCHIDEE model (TRUNK, VPD-AP and SW-AP) were run over a 1,200 $\times 1,200 \mathrm{~km}^{2}$ region covering Amazonia $\left(20^{\circ} \mathrm{S}-10^{\circ} \mathrm{N}\right.$ by $\left.50^{\circ} \mathrm{W}-80^{\circ} \mathrm{W}\right)$ at a $1^{\circ}$ lat/lon spatial resolution. Analysis of the daily outputs was performed at grid-scale across the Amazonian evergreen broadleaved forests. The three versions of ORCHIDEE were forced using 6-hourly CRUNCEP and 3-hourly GSWP3 meteorological data. We used the Zobler soil texture map of the Food and Agriculture Organization (Zobler, 1986). The ORCHIDEE parameter prescribing a maximum LAI was set to be $6.0 \mathrm{~m}^{2} \mathrm{~m}^{-2}$ according to De Weirdt et al. (2012) and consistent with field data from Wu, Albert, et al. (2016). Carbon allocation toward new leaves is stopped in the model when total LAI of the four leaf age classes reaches the maximum LAI (see Section A5 of Krinner et al., 2005). A spin-up run was performed cycling on years 1980-2010 for 230 years, until all vegetation carbon pools had reached an equilibrium and the model was then run for the 1980-2015 period. Plants with similar morphology and behavior were grouped into 13 plant functional types (PFTs) in ORCHIDEE; the PFT maps were derived from the ESA CCI Land Cover maps (Bontemps et al., 2013). This study only considered the grid cells with evergreen broadleaved forest PFT fractions higher than $90 \%$.

\subsection{Evaluation Datasets}

Two gridded satellite observation products were used for model evaluation, as summarized in Table S1 (more details are provided in Supplementary Texts: A). All datasets were aggregated at the same spatial and temporal resolutions than the model outputs (1\%/1-month). For each evaluation product, the model outputs were analyzed over the time period covered by the data set. We used the Enhanced Vegetation Index (EVI) data derived from the Moderate Resolution Imaging Spectroradiometer (MODIS) instrument (Huete et al., 2002; Xu, Saatchi, et al., 2015) to evaluate the seasonal patterns of $\mathrm{LAI}_{\text {young. }}$. We used field observations of seasonal litter fall ( Litt $_{\text {obs }}$ ) (Table S2) from 14 evergreen forest sites across Amazonia (Zhang, Yuan, et al., 2014) and additional litterfall data from literature (Chen et al., 2020). We also used Solar-induced chlorophyll fluorescence (SIF) NASA data derived from the European Global Ozone Monitoring Experi-

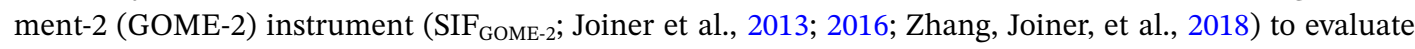
the simulated seasonal patterns of GPP. 


\subsection{Evaluation Metrics}

Two metrics were chosen to evaluate the simulated time series (Mod) against the observation-based datasets (Obs): the Kobayashi decomposition of the Mean Square Difference between model and observation (Kobayashi \& Salam, 2000) and the Nash-Sutcliffe efficiency (NSE) coefficient (Nash \& Sutcliffe, 1970) for gridded fields.

\section{(1) Decomposition of the mean square deviation (MSD) model error}

The mean squared deviation (MSD) is given by Kobayashi and Salam (2000):

$$
\mathrm{MSD}=\frac{1}{n} \sum_{\mathrm{t}=1}^{\mathrm{T}}\left(\operatorname{Mod}_{t}-o b s_{t}\right)^{2}
$$

where $\operatorname{Mod}_{t}$ is the modeled data at time $t$, and $o b s_{t}$ is the observed one at time $t$ (month).

MSD can be decomposed into the sum of three components: the squared bias $\left(d_{\text {bias }}\right)$, the squared difference between standard deviations (variance-related difference, $d_{\mathrm{var}}$ ), and the lack of correlation weighted by the standard deviations (phase-related difference, $d_{\text {phase }}$ ) after (Kobayashi \& Salam, 2000):

$$
\operatorname{MSD}=(\overline{M o d}-\overline{O b s})^{2}+\left(\sigma_{\text {mod }}-\sigma_{\text {obs }}\right)^{2}+2\left(\sigma_{\text {mod }}-\sigma_{\text {obs }}\right)^{2}(1-r)
$$

where $\overline{M o d}$ and $\overline{O b s}$ are the mean of modeled and observed data, $d_{\text {bias }}=(\overline{M o d}-\overline{O b s}), d_{\text {var }}=\left(\sigma_{\text {mod }}-\sigma_{\text {obs }}\right)^{2}$, $d_{\text {phase }}=2\left(\sigma_{\text {mod }}-\sigma_{\text {obs }}\right)^{2}(1-r) ; \sigma_{\text {mod }}$ and $\sigma_{\text {obs }}$ indicate the standard deviation of Mod and Obs, respectively, $r$ indicates the correlation coefficient between Mod and Obs.

GOME-2 SIF were all transformed into a GPP equivalent by fitting a linear regression between FLUXCOM GPP and GOME-2 SIF for all $1^{\circ}$ grid-cells using yearly average data, and then applying this regression to

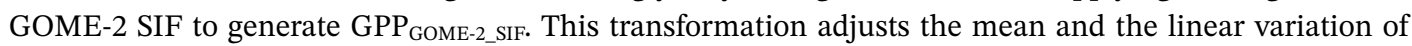
proxies to the mean values of FLUXCOM GPP but preserves the seasonality and spatial patterns of the original proxies.

\section{(2) Nash-Sutcliffe efficiency coefficient}

The Nash-Sutcliffe efficiency (NSE) (Equation 6) is a nonparametric index that quantifies the misfit between two time series, accounting for their differences in terms of phase, amplitude and mean value. It was originally proposed to assess modeled river discharge (Nash \& Sutcliffe, 1970) and is now widely used for hydrological (Krause et al., 2005), climate variables (Fernández-Peruchena, et al., 2015; Soltani et al., 2007), land-atmosphere heat fluxes (Jim \& He, 2011), and GPP (Dass et al., 2016). To compare the phase of seasonality correcting for the impacts of different seasonal amplitudes, we used the Z-transformed variables to calculate the NSE between modeled and observation-based data.

$$
\mathrm{NSE}=1-\frac{\sum_{\mathrm{t}=1}^{\mathrm{T}}\left(\operatorname{Mod}_{t}-o b s_{t}\right)^{2}}{\sum_{\mathrm{t}=1}^{\mathrm{T}}\left(o b s_{t}-\overline{o b s}\right)^{2}}
$$

NSE is sensitive to both absolute values and seasonal variations (K. Wu \& Johnston, 2007). The range of NSE values is $[-\infty, 1]$. An NSE of 1 indicates that the model outputs are exactly the same as the observations; an NSE of 0 indicates that the model outputs perform equivalently to the mean of the observed data. A negative value of NSE indicates that the model outputs perform poorly in comparison with the observed data.

\subsection{Spatial Pattern of Wet-Minus-Dry Season Differences in GPP Across Amazonia}

Following the work of Guan, Pan, et al. (2015), we compared the spatial patterns of the wet- minus dryseason differences $(\Delta)$ between observed and simulated variables. To determine the wet and dry seasons in each grid cell, we defined a month as dry when monthly average precipitation was smaller than the potential 

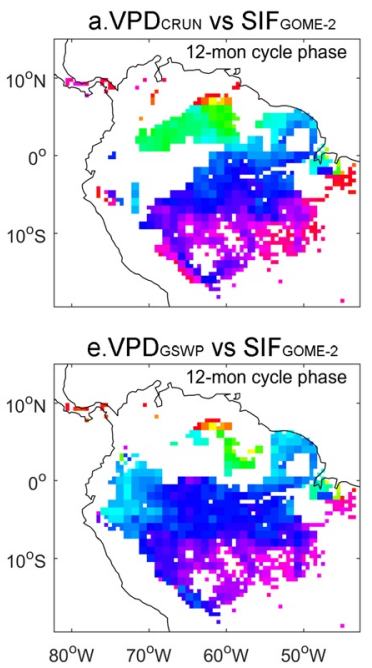

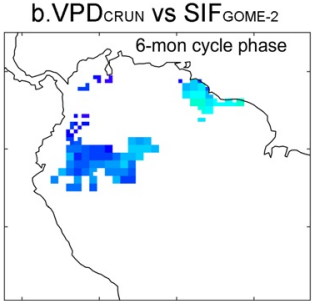

f.VPD gswe VS SIF Gome-2

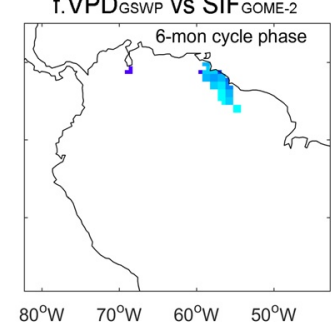

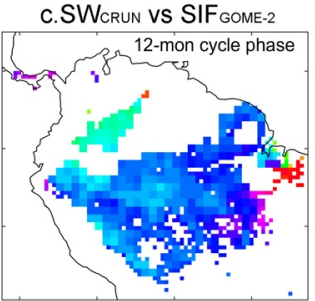

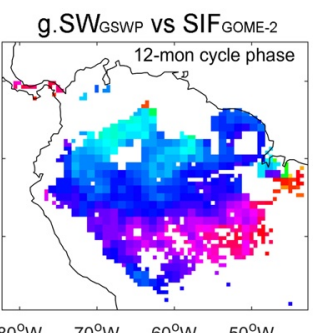

$80^{\circ} \mathrm{W} \quad 70^{\circ} \mathrm{W} \quad 60^{\circ} \mathrm{W} \quad 50^{\circ} \mathrm{W}$

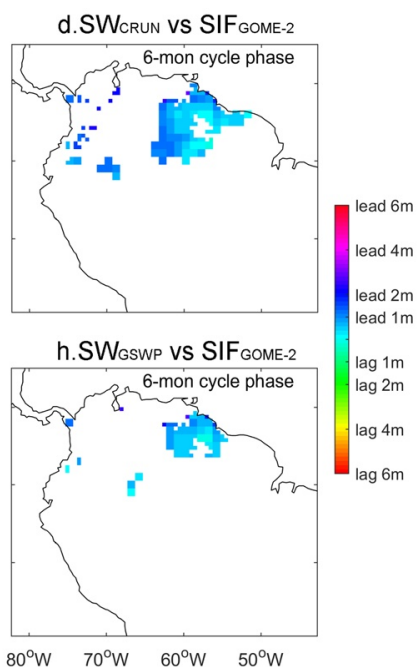

$80^{\circ} \mathrm{W} \quad 70^{\circ} \mathrm{W} \quad 60^{\circ} \mathrm{W} \quad 50^{\circ} \mathrm{W}$

Figure 1. Relative phasing of vapor pressure deficit (VPD) and short-wave (SW) against $\mathrm{SIF}_{\mathrm{GOME}-2}$ for 12- and 6-months cycles-dominated regions, according to spectral analyses. ( $a$ and b) CRUNCEP VPD versus SIF $_{\mathrm{GOME}-2}$ in areas dominated by an annual cycle and a 6-months cycle; (c and d) CRUNCEP SW versus SIF $_{\text {GOME-2 }}$ in areas dominated by an annual cycle and a 6-months cycle; (e and f) GSWP3 VPD versus SIF $_{\text {GOME-2 }}$ in areas dominated by an annual cycle and a 6-months cycle; ( $g$ and $\mathrm{h}$ ) GSWP3 SW versus $\mathrm{SIF}_{\mathrm{GOME}-2}$ in areas dominated by an annual cycle and a 6-months cycle.

evapotranspiration (PET) computed using the method of Maes et al. (2019); other months are defined as wet. $\triangle$ GPP was calculated for each grid cell as the wet-season average GPP value minus the dry-season average value of GPP.

\section{Results}

\subsection{VPD and SW as Triggers of Leaf Shedding}

To verify the assumption that VPD or SW trigger off Amazonian leaf shedding and consequently control canopy photosynthesis, we mapped the regions where VPD and SW are in phase or precede GPP in seasonality given by $\mathrm{SIF}_{\mathrm{GOME}-2}$ observations. A cross-spectral analysis (Bradley et al., 2011) (Supplementary Texts: B) applied to CRUNCEP VPD and CRUNCEP SW showed that in most parts of Amazonia, the seasonality of VPD and SW is dominated by a 12-months seasonal cycle (Figures S1a and S1d), while few northeastern parts of Amazonia off the coast of the Guyana shield rather exhibit a stronger 6-months cycle (Figures S1b and $\mathrm{S} 1 \mathrm{e}$ ). The $\mathrm{SIF}_{\mathrm{GOME}-2}$ signal, although noisy, shows stronger 12-months seasonal cycle in most of Amazonia. Only very few pixels in northern and western regions had stronger 6-months seasonal cycles with two wet seasons (Figure S1c). VPD and SW were found to be either in phase or to lead by 1-2 months than the SIF $_{\mathrm{GOME}-2}$ signal everywhere VPD and SW are dominated by a 12-months seasonal cycle (blue and purple pixels, Figures 1a and 1c). This relationship became weaker however in the north east Guyana shield region where VPD and SW are dominated by a 6-months seasonal cycle (Figure 1). Using GSWP3 climate fields for VPD and SW show similar spatial patterns than using CRUNCEP (blue and purple pixels in Figures 1e and 1g). We concluded from this phase analysis that both VPD and SW were valid predictors of the increase of GPP, which justified their use in the model parameterizations.

\subsection{Leaf Flush and Litterfall Across Amazonia}

Former studies observed that EVI is sensitive to leaf flushing, especially for young leaves aged 2-4 months (Galvão et al., 2011; Gonçalves et al., 2020). To conduct a full spatial evaluation for potential leaf flush, we used the seasonality of EVI to evaluate the seasonality of modeled LAI of young leaves across the Amazonia region. The $\mathrm{LAI}_{\text {young }}$ modeled by TRUNK version ( $\mathrm{LAI}_{\text {trunk, young }}$ ) is always flat and equal to 2.0 throughout the whole year. The AP model results show that, at the BR-Sa1 site (one site in Chen et al. [2020], see also in

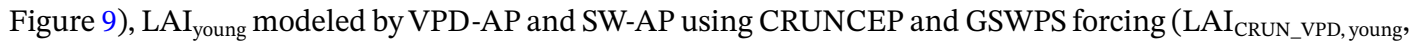
$\mathrm{LAI}_{\mathrm{CRUN} \_S W, \text { young, }}, \mathrm{LAI}_{\mathrm{GSWP}} \mathrm{VPD}_{\text {, young, }}$, and $\mathrm{LAI}_{\mathrm{GSWP}} \mathrm{SW}_{\text {, young }}$ ), perform well for simulating the seasonality against 


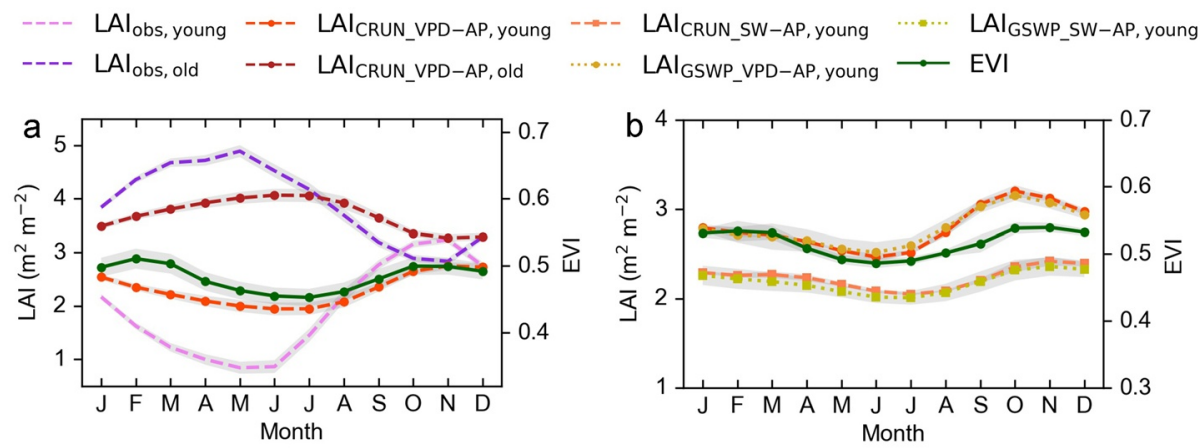

Figure 2. Seasonality of simulated $\mathrm{LAI}_{\text {young }}$ in comparison with observed data. (a) Mean seasonal cycles of

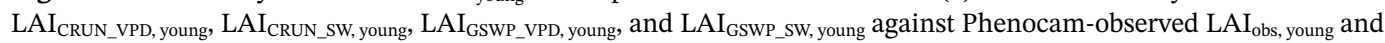
remote sensing Enhanced Vegetation Index (EVI) at the BR-Sa1 site; (b) Mean seasonal cycles of LAI CRUN_VPD, young, $_{\text {, }}$

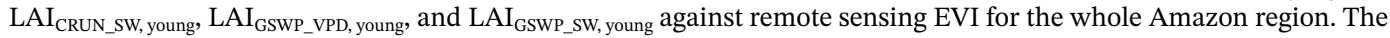
gray shading areas represent the standard error of the mean (SEM).

Phenocam-observed LAI at the BR-Sa1 site (Figure 2a), capturing a dry-season increase trends in LAI of

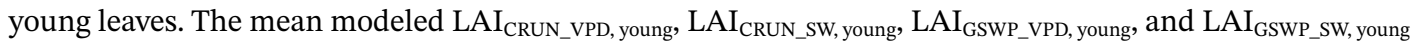
across the whole Amazon all show consistent seasonality with that of EVI (Figure $2 b$ ). At the continent scale, the Pearson correlation values between EVI and $\mathrm{LAI}_{\mathrm{CRUN} \_ \text {VPD, young }}(R=0.78), \mathrm{LAI}_{\mathrm{CRUN} \_ \text {Sw, young }}(R=0.85)$, $\mathrm{LAI}_{\mathrm{GSWP} \_V P D}$ young $(R=0.72)$, and $\mathrm{LAI}_{\mathrm{GSWP} \_s w}$, young $(R=0.94)$ are positive (Figure 3 ).

The litterfall simulation results were compared to the observed seasonality from 14 sites (Zhang, Yuan, et al., 2014). At most sites, the NSE of monthly litterfall was positive, indicating the ability of our model to roughly capture the timing of this process. VPD-AP performed equally as well as SW-AP with CRUNCEP, but was inferior to SW-AP with GSWP3 (Figures 4 and S2). Only at 3 out of 14 sites (Bojaca, La-Es and Jenaro) in the "everwet" western Amazon was the litter fall seasonality poorly represented by all the versions $($ NSEs $<0)$. The VPD-AP model performed better than the SW-AP one at the Tierra and Lago-Ua sites while AP-SW performed better at the Piedras and Gran sites (Figure 4). The SW-AP model was in general more stable in simulating litterfall seasonality than the VPD-AP model when using CRUNCEP or GSWP3 forcing data sets. The lower performances of VPD-AP with GSWP3 may be due to a dry bias of GSWP3 over the Tropics (Boisserie \& Cocke, 2012).

\subsection{GPP Seasonality Across Amazonia}

The GPP seasonality from VPD-AP and SW-AP versions using CRUNCEP and GSWP3 climate forcing data are compared at regional scale in Figure 5. In general, the multiple-year averages of GPP ${ }_{\text {CRUN_VPD-AP, GP- }}$

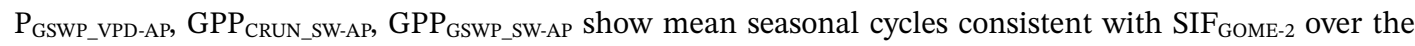
whole Amazonia (Figure 5), with a decrease from May to June and an increase from July to October, in agreement with former studies (Huete et al., 2006; Lee et al., 2013; Lopes et al., 2016; Wu, Albert, et al., 2016; $\mathrm{Xu}$, Saatchi, et al., 2015).

The MSD decompositions (see Section 2.5.1) for GPP simulation misfit against GPP $_{\mathrm{GOME}-2 \_S I F}$ are displayed in Figure 6 for both TRUNK and AP versions. The squared bias was found to be the major contributor to the

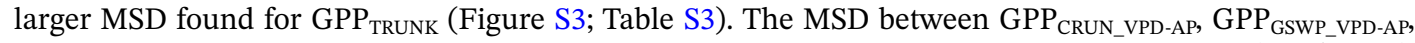
$\mathrm{GPP}_{\mathrm{CRUN} \_\mathrm{SW}-\mathrm{AP}}, \mathrm{GPP}_{\mathrm{GSWP} \_S W-A P}$ and $\mathrm{GPP}_{\mathrm{GOME}-2 \_\mathrm{SIF}}$ were greatly reduced, by on average $0.736 \mathrm{gC}^{2} \mathrm{~m}^{-4} \mathrm{day}^{-2}$, $0.697 \mathrm{gC}^{2} \mathrm{~m}^{-4}$ day $^{-2}, 0.659 \mathrm{gC}^{2} \mathrm{~m}^{-4}$ day $^{-2}$, and $0.612 \mathrm{gC}^{2} \mathrm{~m}^{-4}$ day ${ }^{-2}$ in AP as compared to GPP $\mathrm{TRUNK}$, because of a reduction of both the bias $\left(0.673 \mathrm{gC}^{2} \mathrm{~m}^{-4}\right.$ day $^{-2}, 0.674 \mathrm{gC}^{2} \mathrm{~m}^{-4}$ day $^{-2}, 0.680 \mathrm{gC}^{2} \mathrm{~m}^{-4} \mathrm{day}^{-2}$, and $0.680 \mathrm{gC}^{2}$ $\mathrm{m}^{-4}$ day $\left.^{-2}\right)$ and variance-related terms $\left(0.058 \mathrm{gC}^{2} \mathrm{~m}^{-4}\right.$ day ${ }^{-2}, 0.042 \mathrm{gC}^{2} \mathrm{~m}^{-4} \mathrm{day}^{-2}, 0.038 \mathrm{gC}^{2} \mathrm{~m}^{-4}$ day $^{-2}$, and $0.058 \mathrm{gC}^{2} \mathrm{~m}^{-4} \mathrm{day}^{-2}$ ). The phase-related term of the MSD was smaller than the bias and variance-related terms in both model versions. Nevertheless, the phase-related term of the MSD with AP (Table S3) was also significantly reduced as compared TRUNK, by $0.007 \mathrm{gC}^{2} \mathrm{~m}^{-4}$ day $^{-2},-0.019 \mathrm{gC}^{2} \mathrm{~m}^{-4}$ day ${ }^{-2},-0.058 \mathrm{gC}^{2}$

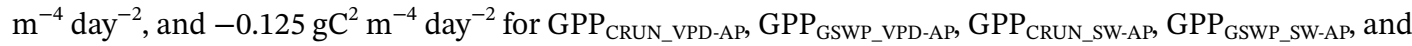
$\mathrm{GPP}_{\mathrm{GOME}-2 \_\mathrm{SIF}}$, respectively. 

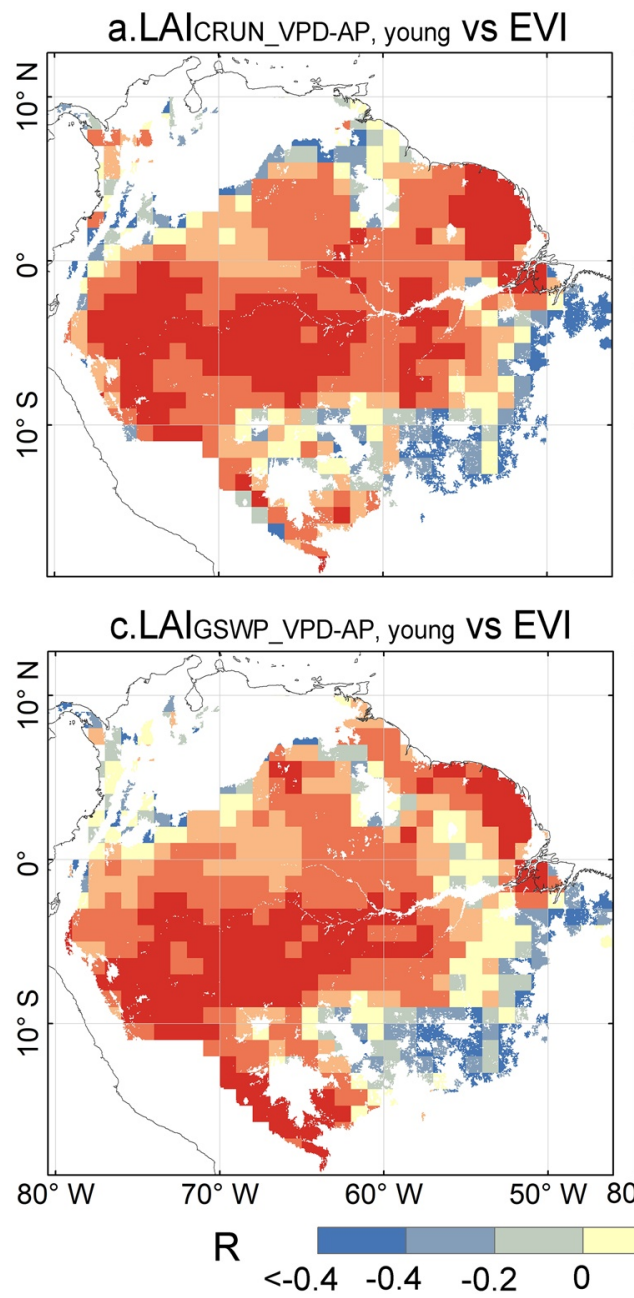

Figure 3. Pearson correlation coefficient $(\mathrm{R})$ between seasonality of simulated $\mathrm{LAI}_{\text {young }}$ and MODIS Enhanced

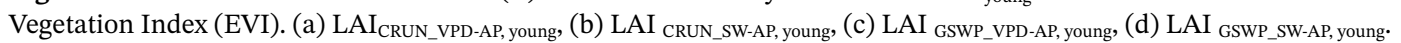

As shown by the MSD analysis, the model error is dominated by the bias and variance-related terms, which masks a detailed assessment of the improved seasonality of AP versus TRUNK. We thus examined NSE, which is a better metric for evaluating seasonal variations. Figure 7 displays maps of NSE for both model versions against the four different GPP proxies, using Z-transformed variables. The AP model better captured the GPP seasonality with $\mathrm{GPP}_{\mathrm{GOME}-2 \text { _SIF }}$ products with the median NSE values of GPP $\mathrm{CRUN}_{\text {_VPD-AP }}$, GP-

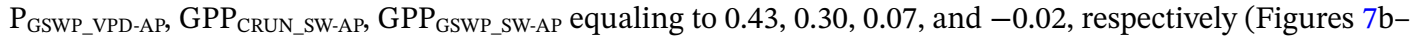
7e, S4; Table S4). In contrast, GPP TRUNK $_{\text {shows a negative median NSE with GPP }}$ GOME-2_SIF (Figures 7a and S4; Table S4). GPP $_{\text {CRUN_VPD }^{-} \text {AP }}$ presents the largest spatial extent of best modeling efficiencies among the four AP versions.

\subsection{Spatial Pattern of Dry-Season Green-Up Across Amazonia}

Guan, Pan, et al. (2015) showed a large-scale dry-season green-up area in the northern wetter part of Amazonia where MAP exceeds 2,000 $\mathrm{mm} \mathrm{yr}^{-1}$. Here, we tested whether VPD- and SW-triggered models can reproduce this green-up spatial pattern against $\mathrm{SIF}_{\mathrm{GOME}-2}$ by investigating differences between wet- and dry-season $(\Delta)$ (Figure 8). Spatial patterns of $\Delta \mathrm{GPP}_{\mathrm{CRUN} \text { VVPD-AP }}$ (Figure 8c) were similar to those of $\Delta \mathrm{SIF}_{\mathrm{GOME}-2}$ (Figure 8b), with higher GPP during the dry season (blue area) almost everywhere north of the Equator. The patterns of $\triangle \mathrm{GPP}_{\mathrm{GSWP}}$ VPD-AP show no dry-season green up pixels (Figure $8 \mathrm{~d}$ ) while SW-AP using both CRUNCEP and GSWP3 forcing show only a thin band of dry season green-up going from the Guyana shield 


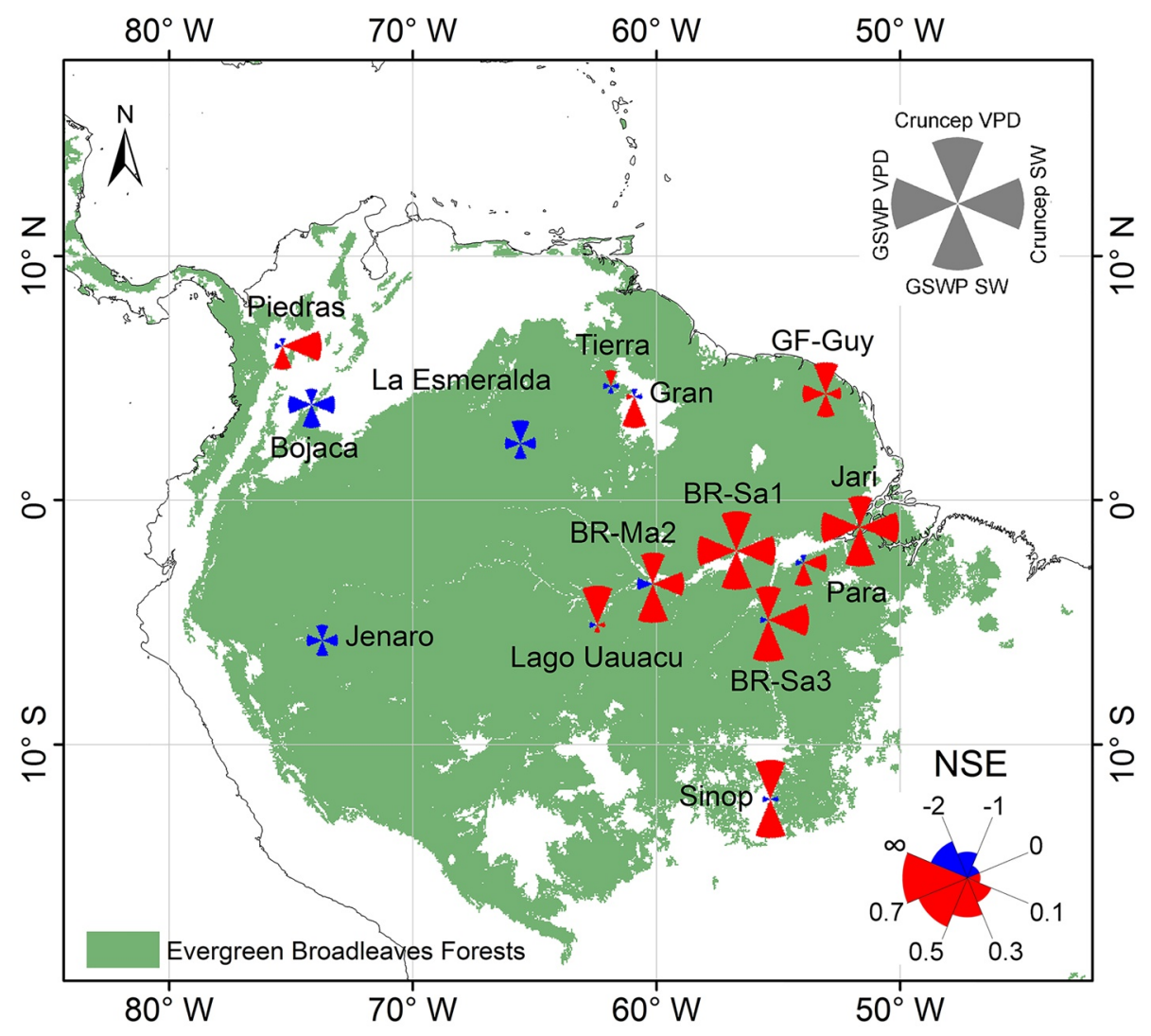

Figure 4. NSE of modeled litterfall for SW-AP and VPD-AP phenology model versions, each version being run with two different climate data sets CRUNCEP and GSWP3 (see legend in upper right corner of the figure). The sector size represents NSE values (red: NSE $>0$; blue color: NSE $<0$ ). The 14 sites correspond to locations where litterfall was monitored.

to Ecuador (Figure 8e). Scatterplots (Figure S5) of modeled $\Delta$ GPP versus observation-based $\Delta$ SIF $_{\mathrm{GOME}-2}$ against MAP also confirmed that VPD-AP and SW-AP using the CRUNCEP forcing perform better in representing the sign of $\triangle$ GPP across Amazonia than those using the GSWP3 forcing. A similar MAP threshold of approximately $2000 \mathrm{~mm} \cdot \mathrm{yr}^{-1}$ was also identified in this study for $\mathrm{SIF}_{\mathrm{GOME}-2}$ (Figure S6k), whereas the distribution of $\mathrm{GPP}_{\mathrm{TRUNK}}$ did not capture this pattern, with only very few grid cells having negative $\Delta$ where MAP $>2,000 \mathrm{~mm} \mathrm{yr}^{-1}$ (Figure S6). We further analyzed the scatterplots of $\Delta$ GPP versus observation-based $\Delta \mathrm{SIF}_{\mathrm{GOME}-2}$ against mean annual SW (Figure S6). Results confirmed that, for most blue grid cells in Figure 8 where the forests show a dry-season green-up, $\mathrm{SIF}_{\mathrm{GOME}-2}$ for most pixels is

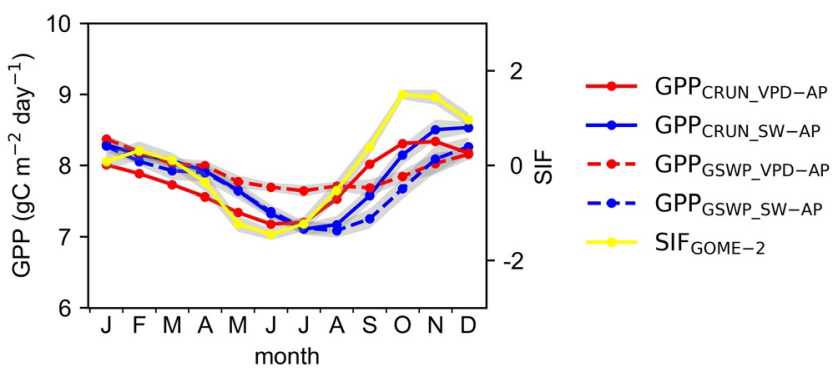

Figure 5. Seasonality of modeled GPP for the VPD-AP and SW-AP phenology schemes. Each version was run with the CRUNCEP (CRUN) and GSWP3 (GSWP) climate forcing data sets. The gray shading areas represent the respective standard error of the mean (SEM), computed over the whole region. not negatively related to SW (blue points in Figure S6). However, for the red grid cells in Figure 8, where forests show a higher GPP in wet season, the $\mathrm{SIF}_{\mathrm{GOME}-2}$ decreases when SW increases in the dry season. Only VPD-AP using the CRUNCEP forcing correctly captures this relationship. Thus, overall, our analysis indicates that VPD-AP using CRUNCEP forcing has a good capability in identifying the spatial patterns of dry-season green-up across Amazonia.

\section{Discussion}

The impacts of seasonal atmospheric dryness and sunlight availability on litterfall and photosynthetic seasonality remain elusive and differ between regions (Leff et al., 2012; Saleska, Miller, et al., 2003; Sayer et al., 2011). Chen et al. (2020) tested the seasonality of precipitation, 


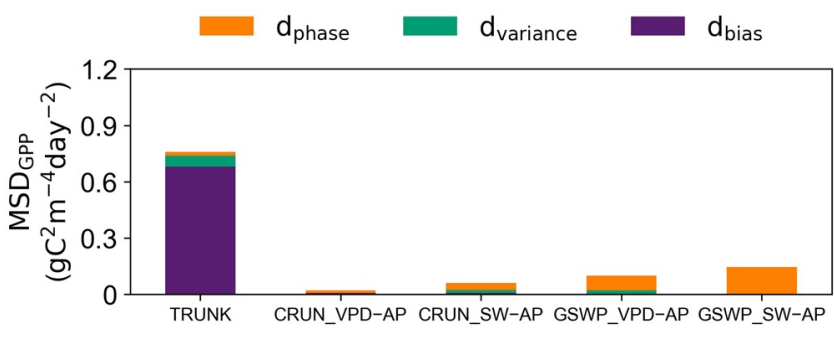

Figure 6. Mean squared deviation (MSD) and its components ( $\mathrm{d}_{\text {bias }}, \mathrm{d}_{\text {var }}$, and $d_{\text {phase }}$ ) between TRUNK/AP modeled GPP CRUN_VPD-AP, GPP $_{\text {GSWP_VPD-AP, }}$

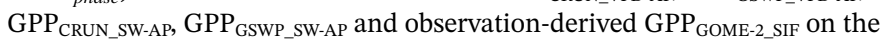
horizontal axis.
SW and VPD as climate triggers of litterfall and suggested that VPD was the best empirical trigger for old leaf shedding at three Amazonian sites with field observations, while no driver worked at the fourth site off the shore of the Guiana coast. Zhou et al. (2019) found that increases of low VPD promoted photosynthesis, while increases in high VPD inhibited it due to stomatal closure. VPD was also suggested as a trigger of old leaf abscission (Myers et al., 1998) and may be a signal for trees to form new leaves that have higher photosynthetic capacity. On the other hand, some studies showed that the increase of SW correlated well with the timing of litter fall (Zhang, Yuan, et al., 2014). A possible reason is that leaves may shed in response to a long decline of solar radiation, after experiencing declining photosynthetic rates (Taiz \& Zeiger, 2002; Zhang, Yuan, et al., 2014). Observations also suggest that most evergreen and deciduous forests in the humid Amazonia both shed mature leaves (Zhang, Yuan, et al., 2014) usually coincident with the production of new leaves when SW begins to increase again with the coming dry season (Descheemaeker et al., 2006; Moraes et al., 1999; Zalamea \& González, 2008). Our VPD-AP model version was shown to capture the photosynthetic seasonality of evergreen forests over a large fraction of the Amazon, and also represented better than the SW-AP version in simulating the large scale dry-season green-up pattern in northern Amazonia. The results, in turn, support the fact that atmospheric dryness and light are credible climatic factors regulating the seasonality of leaf shedding and leaf flush in Amazonian evergreen forests, respectively. The new insights in this study are that we demonstrate the observed seasonal changes in phenology and productivity can be explained if plants adjust their canopy based on changes in climatic variables, which are related to plant resources (water and sunlight) limiting vegetation activity in these regions in a first approximation.
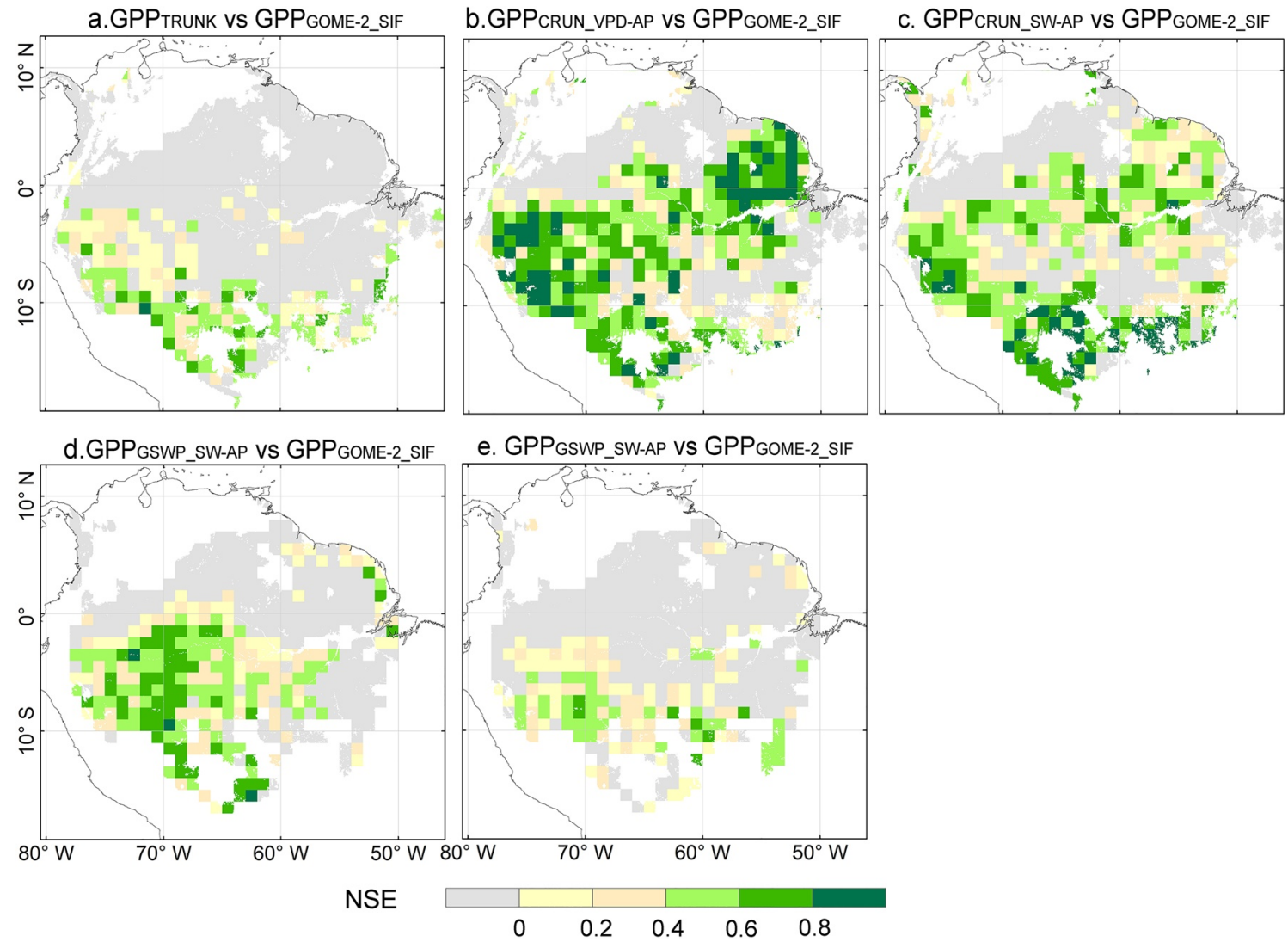

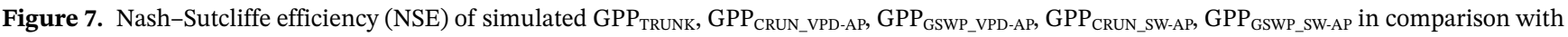
observation-derived $\mathrm{GPP}_{\mathrm{GOME}-2 \text { _SIF. }}$ Gray regions indicate grid cells with NSE $<0$. The NSE was calculated based on Z-transformed variables. 
a.GPPTRUNK

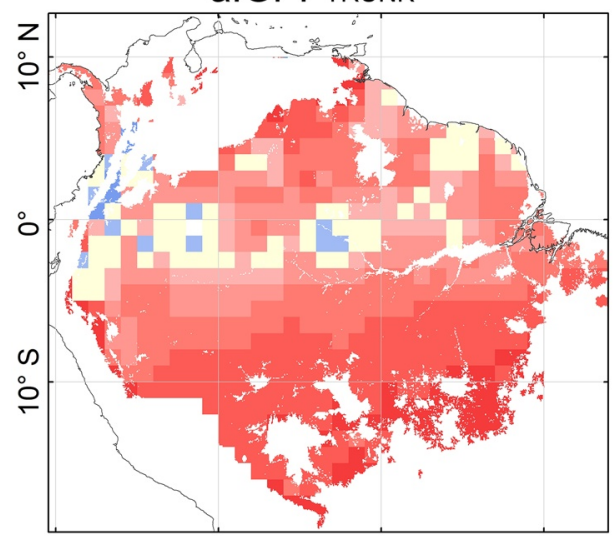

C.GPPCRUN_VPD-AP

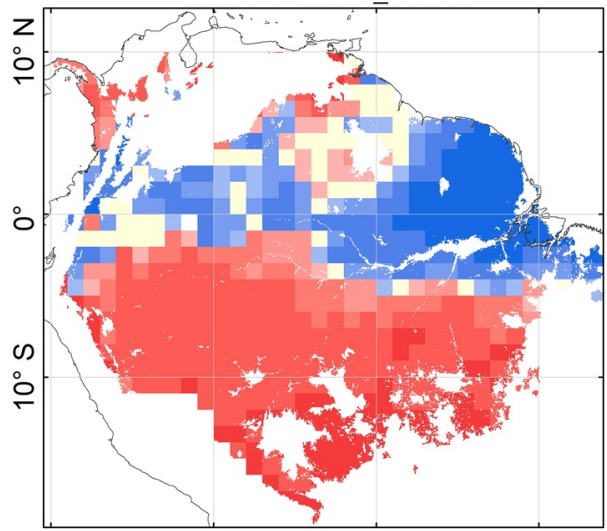

e. GPPCRUN SW-AP

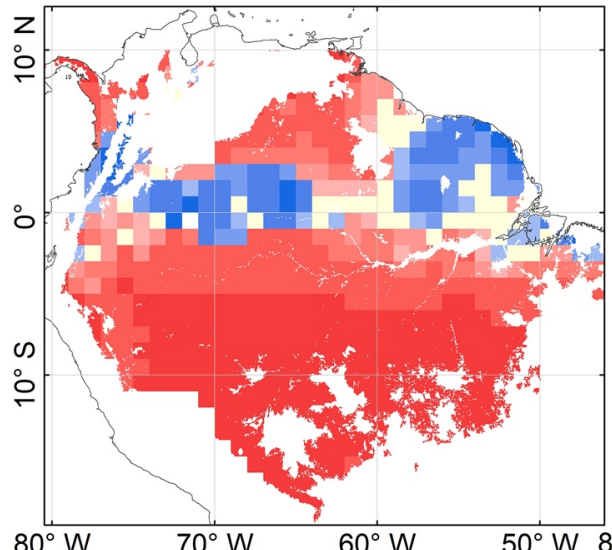

$80^{\circ} \mathrm{W}$ b. SIFGOME-2

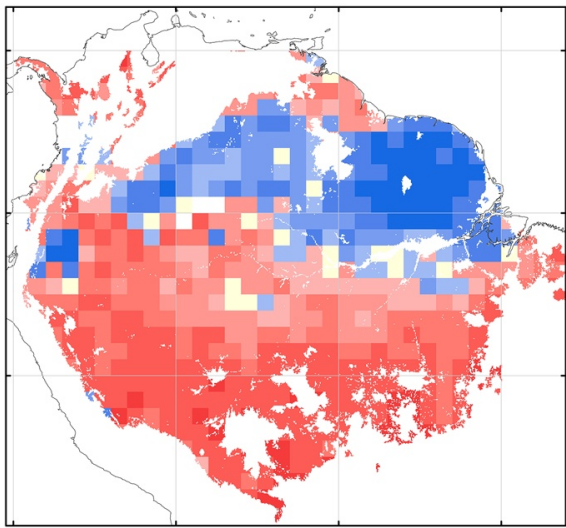

d. GPPGSWP VPD-AP

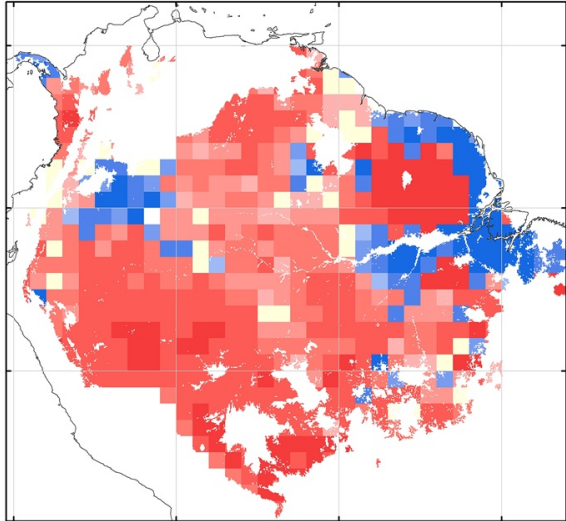

f. GPPGSWP SW-AP

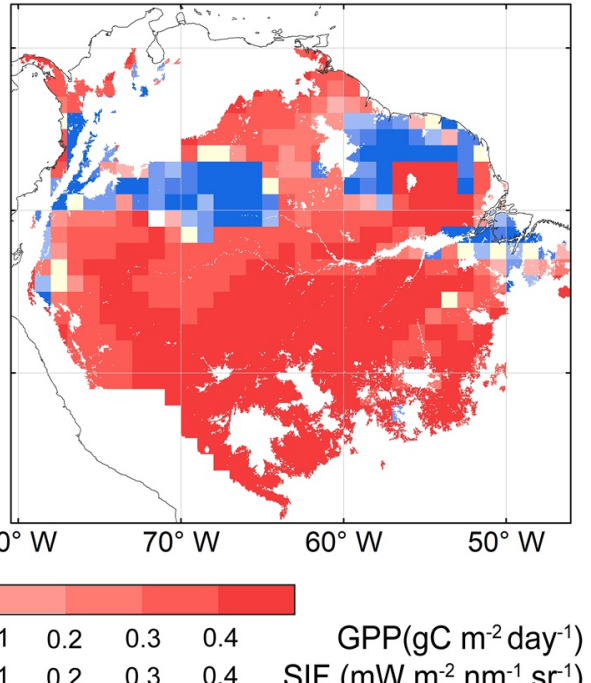

Figure 8. Multi-year average of wet minus dry season differences $(\Delta)$ of simulated $\mathrm{GPP}_{\mathrm{TRUNK}}, \mathrm{GPP}_{\mathrm{CRUN} \text { VPD-AP, }}, \mathrm{GPP}_{\mathrm{GSWP}}$ VPD-AP, $\mathrm{GPP}_{\mathrm{CRUN} \_S W-A P}, \mathrm{GPP}_{\mathrm{GSWP} \_ \text {SW-AP }}$ with satellite $\mathrm{GPP}$ proxies $\left(\mathrm{SIF}_{\mathrm{GOME}-2}\right)$, respectively. Blue indicate regions that show a dry-season green-up or an increase in GPP. 


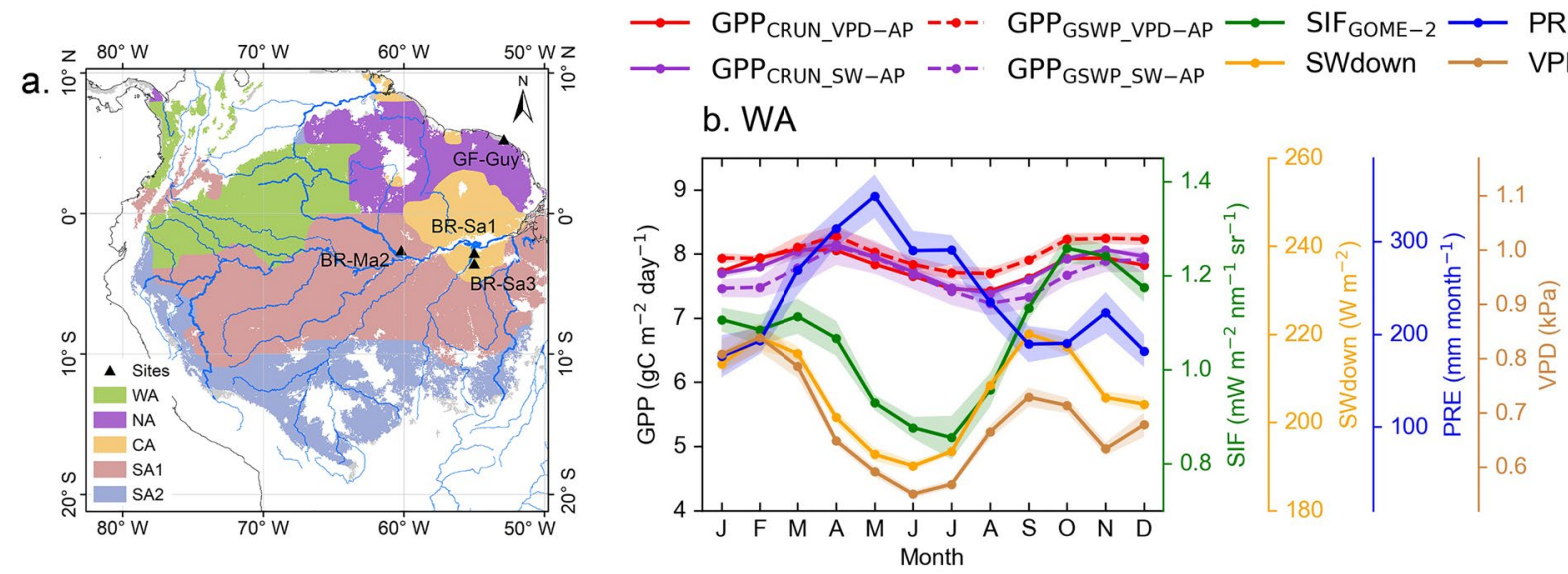

c. NA

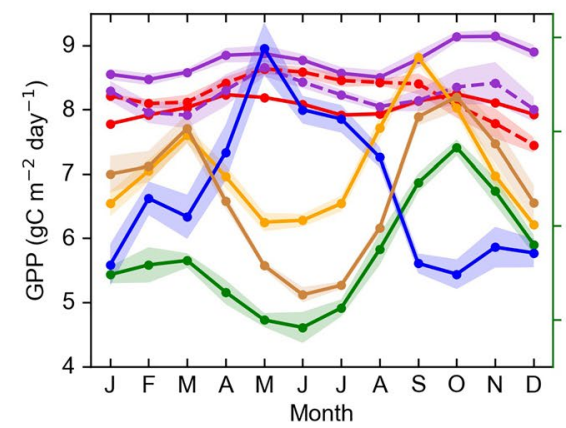

e. SA1

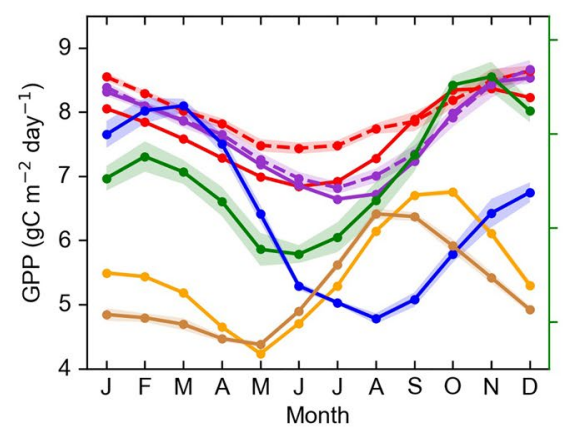

d. CA

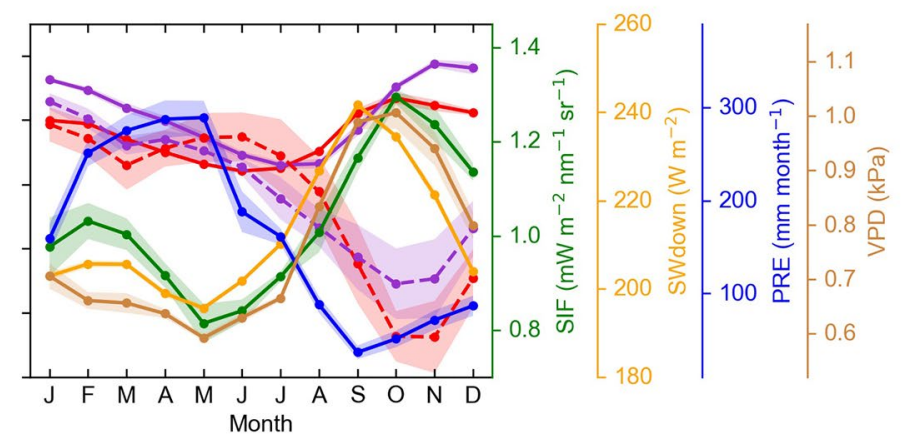

f. SA2
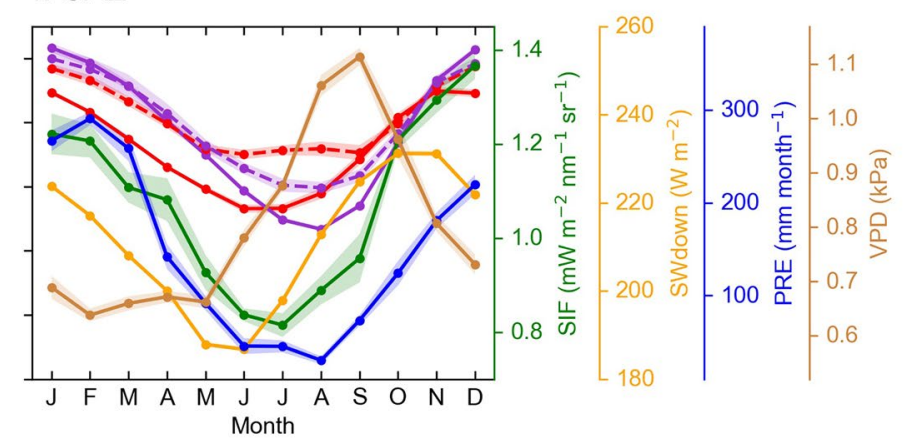

Figure 9. Comparison of simulated and satellite GPP for 5 sub-regions classified by the K-means clustering analysis (see text). The 5 sub-regions are: Northern Amazonia (NA), Western Amazonia (WA), Central Amazonia (CA), Southern Amazonia1 (SA1) and Southern Amazonia2 (SA2). Colored areas correspond to Amazonian evergreen forests with fraction $>90 \%$ based on ESA CCI land cover-derived PFT map. The EC sites used in Chen et al. (2020) are shown for information.

It is worth noting that the VPD-AP model failed to capture the correct GPP seasonality in a Guyana site (Chen et al., 2020). In this study, we found that the Guyana north east region is better captured for the dry season green-up of SIF with the VPD as a trigger compared to SW, but model performances remain poor in this area. Here, we further compared the model results in different sub-regions. As solar radiation and precipitation control the seasonality of sunlight and water availability and in turn influence the tropical phenology and photosynthesis, we classified the Amazon region into 5 sub-regions (Figure 9a) using a K-means clustering analysis (Supplementary Texts: B) based on MAP and SW data from CRUNCEP. The classification results are similar to that of Tang and Dubayah (2017) (Figure S7). The MSD (Table S3, Figure S8) and NSE (Table S4, Figure 7) metrics (Table S3) show that AP versions perform well in CA, SA1, and SA2 sub-regions where the SW seasonality is a unimodal curve. However, AP versions perform poorly in WA and NA regions where SW seasonality is a bimodal curve. We predict that the underlying mechanism 
in triggering the phenology and productivity differ greatly in these regions during the periods of the two GPP peaks.

\section{Conclusions}

This study for the first time integrates site-level process knowledge, which precedes the emergence of new leaves and an increase of GPP generally during the dry season in wet regions of the Amazon, to match diagnostic evidence at large scale. This work is an important step to simulate more realistic impacts of climate change in LSMs for the future, as tropical forests play a major role in global carbon and water cycles. This study showed that our new canopy phenology module implemented into a global LSM can capture the large-scale spatial and seasonal patterns of satellite-observed GPP proxies across Amazonian tropical evergreen forests. The module was originally developed from process understanding and observations of LAI and GPP at one site (Wu, Albert, et al., 2016) and tested at three other sites in Amazonia (Chen et al., 2020). Here, it is shown to provide good results over a large part of Amazonia. Equally important, the new formulation of phenology successfully reproduces the observed MAP threshold of approximately 2,000 $\mathrm{mm} \mathrm{yr}^{-1}$ distinguishing dry-season green-up areas as previously shown in Guan, Pan, et al. (2015).

Our work will improve the representation of leaf phenology and the seasonal controls of productivity in evergreen, broadleaved tropical forests in Earth system models, and has wide implications for assessing historical and predicting future hydrology and carbon cycling in response to climate change. Although using multiple in situ, satellite and modeled data sets for model evaluation, there are still potential limitations due to sparse sites of in situ litterfall measurements, uncertainties of satellite and modeled datasets, and coarse spatial scale of PFT maps in comparison with the real-world spatial heterogeneity. One way forward could be to refine the representation of functional diversity in tropical biomes which are currently not captured by models applying a PFT approach (Franklin et al., 2020). Perspectives for this work include: (a) investigating the different underlying mechanisms of the two GPP peaks in the WA and NA sub-regions where SW also exhibits a bimodal seasonality; (b) extending the modeling exercise to tropical evergreen forests in Africa and South-east Asia in order to improve the photosynthesis and possibly transpiration modeling across the pan-tropics; (c) predicting future changes in tropical phenology, productivity and transpiration in response to future climate changes, which are important for regional and global climate feedbacks.

\section{Data Availability Statement}

The CRUNCEP forcing files are available at website: https://rda.ucar.edu/datasets/ds314.3/. The GSWP3 forcing files are available at website: http://hydro.iis.u-tokyo.ac.jp/GSWP3/. The GOME-2 Solar-Induced Chlorophyll Fluorescence $\left(\mathrm{SIF}_{\mathrm{GOME}-2}\right)$ is available at website: https://avdc.gsfc.nasa.gov/. The MODIS Enhanced Vegetation Index (EVI) data are available at website: https://modis.gsfc.nasa.gov/data/dataprod/ mod13.php. The model outputs and field data used this study are available at: https://doi.org/10.5281/ zenodo.4743415. Natural Science Foundation of China (grant numbers 31971458, 41971275), Innovation Group Project of Southern Marine Science and Engineering Guangdong Laboratory (Zhuhai) (No.311021009), Belgian Science Policy Office (Belspo) - Research Program for Earth Observation, STEREO III, Contract SR/00/334 (ECOPROPHET project), CLIMAX Climate Services Through Knowledge Co-Production: A Euro-South American Initiative For Strengthening Societal Adaptation Response to Extreme Events co-funded by the ANR in the Belmont Forum/ JPI-Climate - Climate Services CRA 201, Special High-level Plan Project of Guangdong Province (grant number 2016TQ03Z354). H. Kim acknowledges support by Grant-in-Aid for Specially promoted Research 16H06291 from JSPS. H. Tang acknowledges support by NASA New Investigator Program (80NSSC18K0708).

\section{References}

Albert, L. P., Wu, J., Prohaska, N., de Camargo, P. B., Huxman, T. E., et al. (2018). Age-dependent leaf physiology and consequences for crown-scale carbon uptake during the dry season in an Amazon evergreen forest. New Phytologist, 218.

Anber, U., Gentine, P., Wang, S., \& Sobel, A. H. (2015). Fog and rain in the Amazon. Proceedings of National Academy Sciences United States of America, 112(37), 11473-11477. https://doi.org/10.1073/pnas.1505077112

Badgley, G., Field, C. B., \& Berry, J. A. (2017). Canopy near-infrared reflectance and terrestrial photosynthesis. Science Advances, 3(3), e1602244. https://doi.org/10.1126/sciadv.1602244

Beer, C., Reichstein, M., Tomelleri, E., Ciais, P., Jung, M., Carvalhais, N., \& Bondeau, A. (2010). Terrestrial gross carbon dioxide uptake: Global distribution and covariation with climate. Science, 1184984.

Bi, J., Knyazikhin, Y., Choi, S., Park, T., Barichivich, J., Ciais, P., et al. (2015). Sunlight mediated seasonality in canopy structure and photosynthetic activity of Amazonian rainforests. Environmental Research Letters, 10(6), 064014. https://doi.org/10.1088/1748-9326/10/6/064014

Boisier, J. P., Ciais, P., Ducharne, A., \& Guimberteau, M. (2015). Projected strengthening of Amazonian dry season by constrained climate model simulations. Nature Climate Change, 5(7), 656-660. https://doi.org/10.1038/nclimate2658

Boisserie, M., \& Cocke, S. (2012). Development of a soil moisture analysis for subseasonal forecasting: Soil moisture validation. Journal of Geophysical Research: Atmosphere, D10, 117.

Bontemps, S., Defourny, P., Radoux, J., Van Bogaert, E., Lamarche, C., Achard, F., et al. (2013). Consistent global land cover maps for climate modelling communities: Current achievements of the ESA's land cover CCI. In Proceedings of the ESA living planet symposium,Edimburgh (pp. 9-13). 
Bradley, A. V., Gerard, F. F., Barbier, N., Weedon, G. P., Anderson, L. O., Huntingford, C., et al. (2011). Relationships between phenology, radiation and precipitation in the Amazon region. Global Change Biology, 17(6), 2245-2260. https://doi.org/10.1111/j.1365-2486.2011.02405.x

Brando, P. M., Goetz, S. J., Baccini, A., Nepstad, D. C., Beck, P. S., \& Christman, M. C. (2010). Seasonal and interannual variability of climate and vegetation indices across the Amazon. Proceedings of the National Academy of Sciences, 200908741.

Chen, X., Maignan, F., Viovy, N., Bastos, A., Goll, D., Wu, J., et al. (2020). Novel representation of leaf phenology improves simulation of Amazonian evergreen forest photosynthesis in a land surface model. Journal of Advances in Modeling Earth Systems, 12(1), e2018MS001565. https://doi.org/10.1029/2018ms001565

Chen, X. Z., Fabienne Maignan, F., Viovy, N., Bastos, A., Goll, D., Wu, J., et al. (2019). Novel representation of leaf phenology improves simulation of Amazonian evergreen forest photosynthesis in a land surface model: Site simulation analysis. Journal of Advances in Modeling Earth Systems, 12, e2018MS001565.

Dass, P., Rawlins, M. A., Kimball, J. S., \& Kim, Y. (2016). Environmental controls on the increasing GPP of terrestrial vegetation across northern Eurasia. Biogeosciences, 13(1), 45-62. https://doi.org/10.5194/bg-13-45-2016

Davidson, E. A., de Araújo, A. C., Balch, J. K., Brown, I. F., Bustamante, M. M., et al. (2012). The Amazon basin in transition. Nature, 481(7381), 321-328. https://doi.org/10.1038/nature10717

De Weirdt, M., Verbeeck, H., Maignan, F., Peylin, P., Poulter, B., Bonal, D., et al., et al. (2012). Seasonal leaf dynamics for tropical evergreen forests in a process-based global ecosystem model. Geoscientific Model Development, 5(5), 1091-1108. https://doi.org/10.5194/ gmd-5-1091-2012

Descheemaeker, K., Muys, B., Nyssen, J., Poesen, J., Raes, D., Haile, M., \& Deckers, J. (2006). Litter production and organic matter accumulation in exclosures of the Tigray highlands, Ethiopia. Forest Ecology and Management, 233(1), 21-35. https://doi.org/10.1016/j. foreco.2006.05.061

Doughty, C. E., Metcalfe, D. B., Girardin, C. A. J., Amézquita, F. F., Cabrera, D. G., Huasco, W. H., et al. (2015). Drought impact on forest carbon dynamics and fluxes in Amazonia. Nature, 519(7541), 78-82. https://doi.org/10.1038/nature14213

Doughty, R., Köhler, P., Frankenberg, C., Magney, T. S., Xiao, X., Qin, Y., et al. (2019). TROPOMI reveals dry-season increase of solar-induced chlorophyll fluorescence in the Amazon forest. Proceedings of the National Academy of Sciences of the United States of America, 116(44), 22393-22398. https://doi.org/10.1073/pnas.1908157116

Fernández-Peruchena, C. M., Blanco, M., Gastón, M., \& Bernardos, A. (2015). Increasing the temporal resolution of direct normal solar irradiance series in different climatic zones. Solar Energy, 115, 255-263. https://doi.org/10.1016/j.solener.2015.02.017

Franklin, O., Harrison, S. P., Dewar, R., Farrior, C. E., Brännström, Å., Dieckmann, U., et al. (2020). Organizing principles for vegetation dynamics. Nature Plants, 6, 444-453.

Galvão, L. S., dos Santos, J. R., Roberts, D. A., Breunig, F. M., Toomey, M., \& de Moura, Y. M. (2011). On intra-annual EVI variability in the dry season of tropical forest: A case study with MODIS and hyperspectral data. Remote Sensing of Environment, 115(9), 2350-2359. https://doi.org/10.1016/j.rse.2011.04.035

Gonçalves, N. B., Lopes, A. P., Dalagnol, R., Wu, J., Pinho, D. M., \& Nelson, B. W. (2020). Both near-surface and satellite remote sensing confirm drought legacy effect on tropical forest leaf phenology after 2015/2016 ENSO drought. Remote Sensing of Environment, 237, 111489. https://doi.org/10.1016/j.rse.2019.111489

Guan, K., Pan, M., Li, H., Wolf, A., Wu, J., Medvigy, D., et al. (2015). Photosynthetic seasonality of global tropical forests constrained by hydroclimate. Nature Geoscience, 8(4), 284-289. https://doi.org/10.1038/ngeo2382

Huete, A., Didan, K., Miura, T., Rodriguez, E. P., Gao, X., \& Ferreira, L. G. (2002). Overview of the radiometric and biophysical performance of the MODIS vegetation indices. Remote Sensing of Environment, 83(1-2), 195-213. https://doi.org/10.1016/s0034-4257(02)00096-2

Huete, A. R., Didan, K., Shimabukuro, Y. E., Ratana, P., Saleska, S. R., Hutyra, L. R., et al. (2006). Amazon rainforests green-up with sunlight in dry season. Geophysical Research Letters, 33(6), L06405. https://doi.org/10.1029/2005gl025583

Jim, C. Y., \& He, H. (2011). Estimating heat flux transmission of vertical greenery ecosystem. Ecological Engineering, 37(8), 1112-1122. https://doi.org/10.1016/j.ecoleng.2011.02.005

Joiner, J., Guanter, L., Lindstrot, R., Voigt, M., Vasilkov, A. P., Middleton, E. M., et al. (2013). Global monitoring of terrestrial chlorophyll fluorescence from moderate spectral resolution near-infrared satellite measurements: Methodology, simulations, and application to GOME-2. Atmosphere Measurement Technique, 6, 2803-2823. https://doi.org/10.5194/amt-6-2803-2013

Joiner, J., Yoshida, Y., Guanter, L., \& Middleton, E. M. (2016). New methods for the retrieval of chlorophyll red fluorescence from hyperspectral satellite instruments: Simulations and application to GOME-2 and SCIAMACHY. Atmospheric Measurement Techniques, 9(8).

Kim, K. (2017). Global Soil Wetness Project Phase 3 Atmospheric Boundary Conditions (Experiment 1) [Data set]. Data Integration and Analysis System (DIAS). https://doi.org/10.20783/DIAS.501

Kobayashi, K., \& Salam, M. U. (2000). Comparing simulated and measured values using mean squared deviation and its components. Agronomy Journal, 92(2), 345-352. https://doi.org/10.1007/s100870050043

Krause, P., Boyle, D. P., \& Bäse, F. (2005). Comparison of different efficiency criteria for hydrological model assessment. Advances in Geosciences, 5, 89-97. https://doi.org/10.5194/adgeo-5-89-2005

Krinner, G., Viovy, N., de Noblet-Ducoudré, N., Ogée, J., Polcher, J., Friedlingstein, P., et al. (2005). A dynamic global vegetation model for studies of the coupled atmosphere-biosphere system. Global Biogeochemical Cycles, 19(1), GB1015. https://doi.org/10.1029/2003gb002199

Lee, J. E., Frankenberg, C., van der Tol, C., Berry, J. A., Guanter, L., Boyce, C. K., \& Badgley, G. (2013). Forest productivity and water stress in Amazonia: Observations from GOSAT chlorophyll fluorescence. Proceedings of the Royal Society B: Biological Sciences, $280,20130171$. https://doi.org/10.1098/rspb.2013.0171

Leff, J. W., Wieder, W. R., Taylor, P. G., Townsend, A. R., Nemergut, D. R., Grandy, A. S., \& Cleveland, C. C. (2012). Experimental litterfall manipulation drives large and rapid changes in soil carbon cycling in a wet tropical forest. Global Change Biology, 18(9), $2969-2979$. https://doi.org/10.1111/j.1365-2486.2012.02749.x

Lopes, A. P., Nelson, B. W., Wu, J., Graça, P. M. L., Tavares, J. V., Prohaska, N., et al. (2016). Leaf flush drives dry season green-up of the Central Amazon. Remote Sensing of Environment, 182, 90-98. https://doi.org/10.1016/j.rse.2016.05.009

Maes, W., Gentine, P., Verhoest, N., \& Gonzalez Miralles, D. (2019). Potential evaporation at eddy-covariance sites across the globe. Hydrology and Earth System Sciences, 23, 925-948.

Manoli, G., Ivanov, V. Y., \& Fatichi, S. (2018). Dry season greening and water stress in Amazonia: The role of modeling leaf phenology. Journal of Geophysical Research, 123. https://doi.org/10.1029/2017JG004282

Moraes, R. M. D., Delitti, W. B. C., \& Struffaldi-De Vuono, Y. (1999). Litterfall and litter nutrient content in two Brazilian Tropical Forests. Brazilian Journal of Botany, 22(1), 09-16. https://doi.org/10.1590/s0100-84041999000100002

Morton, D. C., Nagol, J., Carabajal, C. C., Rosette, J., Palace, M., Cook, B. D., et al. (2014). Amazon forests maintain consistent canopy structure and greenness during the dry season. Nature, 506(7487), 221-224. https://doi.org/10.1038/nature13006 
Myers, B. A., Williams, R. J., Fordyce, I., Duff, G. A., \& Eamus, D. (1998). Does irrigation affect leaf phenology in deciduous and evergreen trees of the savannas of northern Australia? Austral Ecology, 23(4), 329-339. https://doi.org/10.1111/j.1442-9993.1998.tb00738.x

Nash, J. E., \& Sutcliffe, J. V. (1970). River flow forecasting through conceptual models part I - A discussion of principles. Journal of hydrology, 10(3), 282-290. https://doi.org/10.1016/0022-1694(70)90255-6

Parazoo, N. C., Bowman, K., Frankenberg, C., Lee, J.-E., Fisher, J. B., Worden, J., et al. (2013). Interpreting seasonal changes in the carbon balance of southern Amazonia using measurements of $\mathrm{XCO}_{2}$ and chlorophyll fluorescence from GOSAT. Geophysical Research Letters, 40(11), 2829-2833. https://doi.org/10.1002/grl.50452

Restrepo-Coupe, N., da Rocha, H. R., Hutyra, L. R., da Araujo, A. C., Christoffersen, B., Cabral, O. M. R., et al. (2013). What drives the seasonality of photosynthesis across the Amazon basin? A cross-site analysis of eddy flux tower measurements from the Brasil flux network. Agricultural and Forest Meteorology, 182-183, 128-144. https://doi.org/10.1016/j.agrformet.2013.04.031

Restrepo-Coupe, N., Levine, N. M., Christoffersen, B. O., Albert, L. P., Wu, J., Costa, M. H., et al. (2017). Do dynamic global vegetation models capture the seasonality of carbon fluxes in the Amazon basin? A data-model intercomparison. Global Change Biology, 23(1), 191-208. https://doi.org/10.1111/gcb.13442

Saleska, S. R., Miller, S. D., Matross, D. M., Goulden, M. L., Wofsy, S. C., Rocha, D. , H. R., et al. (2003). Carbon in Amazon forests: Unexpected seasonal fluxes and disturbance-induced losses. Science, 302(5650), 1554-1557. https://doi.org/10.1126/science.1091165

Saleska, S. R., Wu, J., Guan, K., Araujo, A. C., Huete, A., Nobre, A. D., \& Restrepo-Coupe, N. (2016). Dry-season greening of Amazon forests. Nature, 531(7594). https://doi.org/10.1038/nature16457

Samanta, A., Costa, M. H., Nunes, E., Vieira, S. A., Xu, L., \& Myneni, R. B. (2011). Comment on "Drought-Induced Reduction in Global Terrestrial Net Primary Production from 2000 Through 2009”. Science, 333(10932011). https://doi.org/10.1126/science.1199048

Samanta, A., Ganguly, S., Hashimoto, H., Devadiga, S., Vermote, E., Knyazikhin, Y., et al. (2010). Amazon forests did not green-up during the 2005 drought. Geophysical Research Letters, 5, 37.

Samanta, A., Ganguly, S., \& Myneni, R. B. (2011). MODIS Enhanced Vegetation Index data do not show greening of Amazon forests during the 2005 drought. New Phytologist, 189(1), 11-15. https://doi.org/10.1111/j.1469-8137.2010.03516.x

Sayer, E. J., Heard, M. S., Grant, H. K., Marthews, T. R., \& Tanner, E. V. J. (2011). Soil carbon release enhanced by increased tropical forest litterfall. Nature Climate Change, 1(6), 304-307. https://doi.org/10.1038/nclimate1190

Soltani, S., Modarres, R., \& Eslamian, S. S. (2007). The use of time series modeling for the determination of rainfall climates of Iran. International Journal of Climatology, 27(6), 819-829. https://doi.org/10.1002/joc.1427

Spracklen, D. V., Arnold, S. R., \& Taylor, C. M. (2012). Observations of increased tropical rainfall preceded by air passage over forests. Nature, 489(7415), 282-285. https://doi.org/10.1038/nature11390

Taiz, L., \& Zeiger, E. (2002). Plant Physiology (3rd ed.), Sunderland: Sinauer Associates.

Tang, H., \& Dubayah, R. (2017). Light-driven growth in Amazon evergreen forests explained by seasonal variations of vertical canopy structure. Proceedings of the National Academy of Sciences of the United States of America,114, 2640-2644. https://doi.org/10.1073/ pnas.1616943114

Van der Ent, R. J., Wang-Erlandsson, L., Keys, P. W., \& Savenije, H. H. G. (2014). Contrasting roles of interception and transpiration in the hydrological cycle - Part 2: Moisture recycling. Earth Systems Dynamics, 5(2), 471-489. https://doi.org/10.5194/esd-5-471-2014

Viovy, N. (2018). CRUNCEP Version 7-Atmospheric Forcing Data for the Community Land Model. Research Data Archive at the National Center for Atmospheric Research. Computational and Information Systems Laboratory. Retrieved from http://rda.ucar.edu/datasets/ ds314.3/

Wright, S. J., \& Van Schaik, C. P. (1994). Light and the phenology of tropical trees. The American Naturalist, 143(1), 192-199. https://doi. org/10.1086/285600

Wu, J., Albert, L. P., Lopes, A. P., Restrepo-Coupe, N., Hayek, M., Wiedemann, K. T., et al. (2016). Leaf development and demography explain photosynthetic seasonality in Amazon evergreen forests. Science, 351(6276), 972-976. https://doi.org/10.1126/science.aad5068

Wu, J., Guan, K., Hayek, M., Restrepo-Coupe, N., Wiedemann, K. T., Xu, X., et al. (2017). Partitioning controls on Amazon forest photosynthesis between environmental and biotic factors at hourly to interannual timescales. Global Change Biology, 23(3), 1240-1257. https:// doi.org/10.1111/gcb.13509

Wu, J., Kobayashi, H., Stark, S. C., Meng, R., Guan, K., Tran, N. N., et al. (2018). Biological processes dominate seasonality of remotely sensed canopy greenness in an Amazon evergreen forest. New Phytologist, 217(4), 1507-1520. https://doi.org/10.1111/nph.14939

Wu, J., Serbin, S. P., Xu, X., Albert, L. P., Chen, M., Meng, R., et al. (2017). The phenology of leaf quality and its within-canopy variation is essential for accurate modeling of photosynthesis in tropical evergreen forests. Global Change Biology, 23(11), 4814-4827. https://doi. org/10.1111/gcb.13725

Wu, K., \& Johnston, C. A. (2007). Hydrologic response to climatic variability in a Great Lakes Watershed: A case study with the SWAT model. Journal of Hydrology, 337(1-2), 187-199. https://doi.org/10.1016/j.jhydrol.2007.01.030

Xiao, X., Zhang, Q., Saleska, S., Hutyra, L., De Camargo, P., Wofsy, S., et al. (2005). Satellite-based modeling of gross primary production in a seasonally moist tropical evergreen forest. Remote Sensing of Environment, 94(1), 105-122. https://doi.org/10.1016/j.rse.2004.08.015

Xu, L., Saatchi, S. S., Yang, Y., Myneni, R. B., Frankenberg, C., Chowdhury, D., \& Bi, J. (2015). Satellite observation of tropical forest seasonality: Spatial patterns of carbon exchange in Amazonia. Environmental Research Letters, 10(8), 084005.

Xu, X., Medvigy, D., Joseph Wright, S., Kitajima, K., Wu, J., Albert, L. P., et al. (2017). Variations of leaf longevity in tropical moist forests predicted by a trait-driven carbon optimality model. Ecology Letters, 20(9), 1097-1106. https://doi.org/10.1111/ele.12804

Zalamea, M., \& González, G. (2008). Leaffall phenology in a subtropical wet forest in Puerto Rico: from species to community patterns. Biotropica, 40(3), 295-304.

Zhang, H., Yuan, W., Dong, W., \& Liu, S. (2014). Seasonal patterns of litterfall in forest ecosystem worldwide. Ecological Complexity, 20, 240-247. https://doi.org/10.1016/j.ecocom.2014.01.003

Zhang, Y., Joiner, J., Alemohammad, S. H., Zhou, S., \& Gentine, P. (2018). A global spatially contiguous solar-induced fluorescence (CSIF) dataset using neural networks. Biogeosciences, 15(19). https://doi.org/10.5194/bg-15-5779-2018

Zhou, S., Zhang, Y., Williams, A. P., \& Gentine, P. (2019). Projected increases in intensity, frequency, and terrestrial carbon costs of compound drought and aridity events. Science Advances, 5(1), eaau5740. https://doi.org/10.1126/sciadv.aau5740

Zobler, L. (1986). A world soil file for global climate modeling. Technical Report. NASA. 